\title{
Design and Simulation of Gannan Forest Change Based on CA- Markov Model
}

\author{
Li Yang ${ }^{1, *}$, Chun $\mathrm{Fu}^{2}$ and Hao Chen ${ }^{3}$ \\ ${ }^{1}$ Management Department of Nanchang University, Nanchang, 330031, China \\ and Science Department of Nanchang University, Nanchang, 330031, China \\ ${ }^{2}$ Center for Central China Economic Development Research of Nanchang \\ University, Nanchang, 330031, China \\ ${ }^{3}$ School of Economics and Management of Nanchang University, Nanchang, \\ 330031, China \\ Corresponding Author: Li Yang, yangli46@ncu.edu.cn
}

\begin{abstract}
Changes in forest cover are a matter of global interest. Gannan is an important ecological barrier in southeastern China. As rapid urbanization has led to increasing illegal occupation of forest land, more attention must be paid to forest resources in Gannan. This study aimed to explore changes in use of forest land in Gannan, China based on Landsat TM/ETM remote sensing data for the years 2000, 2005 and 2010. By grouping forest land use into four categories, we mapped land uselland cover change (LUCC) and predicted future patterns. The study were divided into 3 parts: 1) mapping LUCC in the region between 2000 and 2005; 2) applying the Markov-cellular automata technique to these maps to predict potential changes in 2010 and to test the accuracy of the prediction; and 3) predicting the land cover distribution in 2020. Results show that: In 2000-2005, Woodlands tended to change from high canopy density to low canopy density forest lands, which indicated degradation of forest stands. If patterns of land use change continue, the extent of closed forest, shrubbery and open forest will decrease. In Gannan, woodland area is increasing but woodland quality is declining, which means that forest resources are undergoing degeneration.
\end{abstract}

Keywords: Cellular automata; Forest land cover; Gannan; LUCC; Markov

\section{Introduction}

Forests represent a large proportion of terrestrial ecosystems. Forestland makes a strong contribution to mitigation of climate change, maintenance of the global carbon balance, protection of biodiversity, conservation of soil and water, and protection against erosion by wind and water (Mayer et al. 2005). Forests are strongly affected by anthropogenic activity and natural disasters, and degradation of forested areas is increasing on a global scale. Monitoring and analyzing variation in forestland is of theoretical and practical significance to reveal mechanisms behind these changes and to analyze and evaluate the regional ecological environment (Overpeck et al. 1990). Changes in forest cover have attracted international attention. These changes are largely a result of land use and land cover change (LUCC) (Uddin et al. 2015), about which an increasing number of studies have been conducted (Lambin et al. 2003; Verburg et al. 2011; Wardell et al 2003). LUCC is one of the main factors influencing our daily life (Foley et al. 2005), and estimation of spatiotemporal changes in forest area is an issue of international importance (Kumar et al. 2014).

Methods to study spatiotemporal changes in LUCC and the consequences of these changes are improving rapidly; a new methodological framework has been established 
that integrates classical geographical theory with remote sensing and geographic information systems (GIS) (Liu et al. 2010). Global changes in land use are examined using parameterization and quantization. The use of remote sensing data in studies of forest area facilitates understanding of how LUCC influences climate, biodiversity and carbon emissions (Falcucci et al. 2007; Serra et al. 2008; Hansen et al. 2012; Chen et al. 2007). Combining satellite remote sensing data with field surveys is important when estimating changes in forest cover. Many researchers have combined remote sensing and GIS to effectively monitor forest cover (Martinez et al. 2015; Srivastava et al. 2015; Simoniello et al. 2015; Mullerova et al. 2014), and new developments in these technologies enable more efficient modeling and prediction of LUCC. Markov models are often used to simulate land use in defined areas because they enable accurate quantification and fusion with spatial models. However, Markov models lack spatial variables. Cellular automata (CA) models are classical models of land use that can simulate the dynamic spatiotemporal evolution of complex systems ( Rujian, 1987). The combination of CA and Markov models enables simulation of spatial land cover changes and forecasting of long-term trends. CA-Markov method have been proved to be effective tool to simulate spatial forest land use change (Tattoni et al. 2011; Mukhopadhyay et al. 2015; Cabra et al. 2009; Green et al. 2016). In our study, CA-Markov is applied to examine forest changes of Gannan in China in terms of detailed forest land cover classification. Gannan's forest land are subdivided into closed forest land, shrubbery, open forest land and other forest land and based on this classification, we mapped Gannan's land use/land cover changes and predicted future patterns. The article were to: 1) map LUCC in the region around Gannan, China between 2000 and 2005; 2) apply the CA-Markov technique to these LUCC maps to simulate potential changes in 2010 and to test the accuracy of the prediction; and 3) predict the potential changes in 2020 and analyze the variation pattern.

\section{Materials and Methods}

\subsection{Study Area and Field Data}

Gannan is a city in southern Jiangxi Province, China, where three large mountains converge (Nanling, Wuyi and Zhuguang). It is at the southern edge of the subtropical zone, at the boundary of China's southern and northern subtropical climates. See its location in Figure 1.

Gannan is an important ecological barrier in southeastern china and is called the "Ecological Kingdom" and "Green Treasure House". In 2012, China's State Council issued suggestions to support the promotion and development of former Soviet Central areas such as Gannan (China State Council, 2012). This document describes how to implement the southeastern ecological security barrier and how to use ecological engineering and green industry to maintain ecological security and to promote regional sustainable development in southeastern China.

Ecosystems in Gannan have been severely damaged during the last century. Since 1984, a series of national ecological projects has been carried out, including a 10-year "greening" program and suspension of logging in natural broad-leaved forest (Song X et al. 2015). According to China's "11th five-year plan" (The fourth session of the Tenth National People's Congress, 2006), by the end of 2010, the city's forest cover was $76.2 \%$, with a total standing stock of 119.22 million $\mathrm{m} 3$ and area of 3.06 million ha. Although these values are large, there are still a lot of problems, such as the high percentage of young and middle-aged trees, the unitary species composition of the plants, severe water and soil loss and so on. 
With rapid urbanization, illegal occupation of forest land is increasingly common in China. More attention must be paid to forest resources in Gannan in order to meet the dual needs of ecological conservation and economic development.

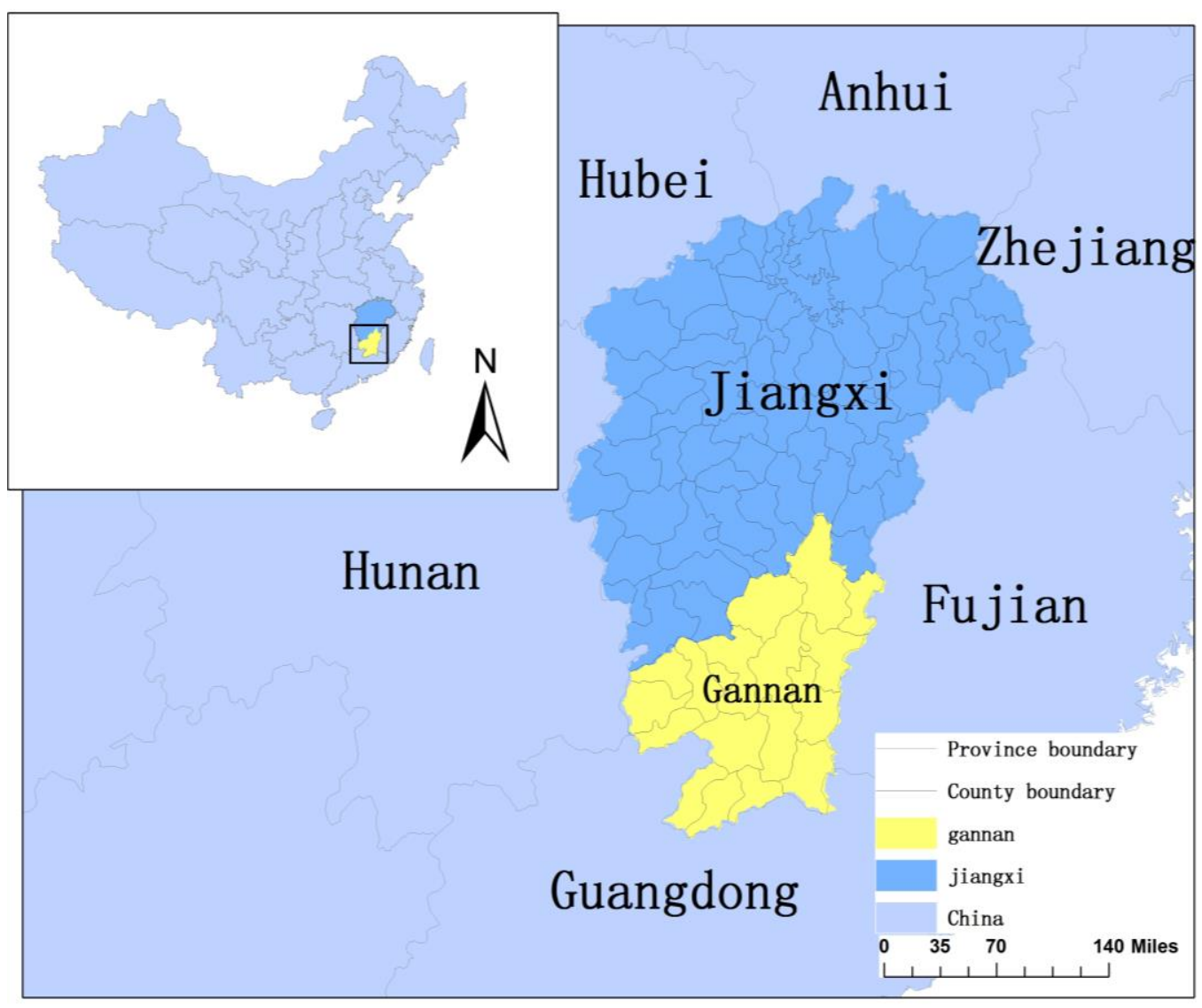

Figure 1. Location of Gannan

\subsection{Data Resources}

A dataset was provided by Data Center for Resources and Environmental Sciences, Chinese Academy of Sciences (RESDC) (http://www.resdc.cn), including remote sensing information on land use in 2000, 2005 and 2010. These data were generated by visual interpretation, mainly based on Landsat TM/ETM remote sensing images in each phase. The database was in grid format (grid size $1000 \mathrm{~m} \times 1000 \mathrm{~m}$ ).

\subsection{Land Use/Forest Cover Classification}

Because our objective was to assess changes in forest land cover, we classified land use into eight categories (Table 1). These eight land categories corresponded to 8 cellular statuses in CA model. 
Table 1. Classification and Coding of Land Use

\begin{tabular}{lcl}
\hline \multicolumn{1}{c}{ Category } & Code & \multicolumn{1}{c}{ Definition } \\
\hline Farmland & 1 & $\begin{array}{l}\text { Irrigated and non-irrigated farmlands } \\
\text { Natural forests and plantations with canopy density }>30 \%, \\
\text { including woodlands such as timber stands, economic forests } \\
\text { and protective forests }\end{array}$ \\
Closed forest land & 2 & $\begin{array}{l}\text { Coppice-lands and scrub woodlands with canopy density } \\
>40 \% \text { and height }<2 \mathrm{~m}\end{array}$ \\
Shrubbery & 3 & $\begin{array}{l}\text { Forest lands with canopy density of 10\% to 30\% } \\
\text { Open forest land }\end{array}$ \\
Other forest land & 5 & $\begin{array}{l}\text { Young afforested lands, slash, plant nurseries and garden } \\
\text { plots }\end{array}$ \\
Grassland & 6 & $\begin{array}{l}\text { Grasslands with high, middle and low percent cover } \\
\text { River and canals, lakes, reservoir pits, permanent ice and } \\
\text { snow, tidal flats and beaches }\end{array}$ \\
Urban and rural & 7 & $\begin{array}{l}\text { Urban lands, rural residential areas and other lands } \\
\text { designated for construction }\end{array}$ \\
\hline
\end{tabular}

\subsection{CA-Markov model}

The Markov model is a stochastic process model that describes the likelihood of one state changing to another state. Transition probability matrix is its key-descriptive tool (Mousivand et al. 2007). The model is defined as a set of states where a process begins in one of the states and moves consecutively from one state to another; each move is defined as a step (Zhang et al. 2010). Cellular automata model is a well-known simulation model where space and time are discrete and interactions are only local. The space is separated into regular cells and the state of each particular cell is determined by the state of the cell itself, as well as its surrounding cells, at a previous time period through a set of predefined transition rules (Jokar et al. 2013) .The incorporation of neighboring states through a combination of Markov and cellular automata (CA-Markov) approaches can improve models that describe complex natural patterns (Guan DJ et al. 2011). Future cover status was then predicted using a CA-Markov model based on the 2000 and 2005 land-cover classifications and the transition matrices, probability maps, and contiguity. Transition matrices, representing the probability of changes between individual cover types, were calculated for two periods, 2000-2005 and 2005-2010, using the corresponding grids.

In our research, the cellular space was the entire grid area of Gannan, and the cellular neighborhood was an $\mathrm{N} \times \mathrm{N}$ land-use matrix. Markov models have no spatial variables, while the variables in CA models are closely combined with spatial location; thus, the CA-Markov approach is an effective combination of the two methods. CA-Markov first generates a transfer matrix and transfer suitability images. A CA filter is then constructed according to a spatial weighting factor; CA transfer rules and boundaries can also be built based on the transfer matrix. Finally, changes in every cell can be predicted. The CAMarkov approach enables determining of transfer rules and consideration of spatial factors. 


\subsection{Research Process}

Land cover change can be regarded as a Markov process, and every pixel is considered a cell. Land cover categories correspond to cellular status, and neighboring pixels are cellular neighbors. The land cover type of the central cell is finally determined using transfer rules according to its land cover type and its neighbors in the previous time step.

The detailed steps are as follows:

1) The remote sensing data of land use in Gannan are first transferred into ASCII format under ArcGIS platform and imported into IDRISI 17.0 to become raster form.

2) Based on land cover status of 2000 and 2005 in Gannan, Markov module in IDRISI was called to obtain a land cover transfer probability matrix.

3) Setting land use cover of 2005 as the beginning of the varying pattern, we predict land cover distribution in 2010. CA-markov module is called to conduct the prediction. The Cellular Automata filter type was set as Standard 5*5 contiguity filter, which means a $5 \times 5$ pixel space is considered to have significant influence on the central cell.

4) Perform validation of model results, and conduct precision analysis.

5) Similarly, setting the real land use cover of 2010 as the beginning of the varying pattern and calculating the land use transfer probability matrix based on land use in 2005 and 2010, as in the previous steps, we predict the land cover distribution in 2020.

\section{Results and Discussion}

\subsection{Land Use Transfer Matrix}

Using remote sensing information on land use in 2000 and 2005 as input for a Markov model, land use transfer probability is obtained (Table 2).

Land cover transformation from 2000 to 2005 can be seen from Table 2. First, from the perspective of to which 4 forest lands transfer, we can conclude that closed forest land and shrubbery mostly was transferred to other forest land cover types, and the primary conversion of open and other forest land was to farmland. What's more, a relatively large proportion of open forestland was also converted to other forest land. On the whole, forest land was mainly converted to other forest types and to farmland.

Next, we asked what land types were transferred to forest land. The transfer sources of closed forest land were relatively scattered and included farmland, shrubbery, grassland and urban and rural land. Urban and rural lands are the only types that would convert to shrub cover. There were fewer transfer sources of open forest land compared to closed forest land. Only a small proportion of farmland, closed forest, and urban and rural land transferred to open forest. In all, each land cover type could transfer to other types of forest land, but the primary transfer sources were closed forest, farmland and shrubbery.

Table 2. Markovian Transition Probability Matrices of 2000-2005

\begin{tabular}{lcccccccc} 
Land Use Type & 1 & 2 & 3 & 4 & 5 & 6 & 7 & 8 \\
\hline Farmland & 0.85 & 0.02 & 0.00 & 0.01 & 0.11 & 0.00 & 0.00 & 0.02 \\
\hline Closed forest land & 0.03 & 0.83 & 0.00 & 0.01 & 0.12 & 0.00 & 0.00 & 0.00 \\
\hline Shrubbery & 0.02 & 0.03 & 0.84 & 0.00 & 0.09 & 0.00 & 0.00 & 0.01 \\
\hline Open forest land & 0.08 & 0.02 & 0.00 & 0.84 & 0.05 & 0.00 & 0.00 & 0.00 \\
\hline Other forest land & 0.16 & 0.00 & 0.00 & 0.00 & 0.84 & 0.00 & 0.00 & 0.00 \\
\hline Grassland & 0.11 & 0.02 & 0.00 & 0.02 & 0.02 & 0.83 & 0.00 & 0.00 \\
\hline Aquatic area & 0.15 & 0.00 & 0.00 & 0.00 & 0.00 & 0.00 & 0.85 & 0.00 \\
\hline Urban and rural & 0.02 & 0.02 & 0.02 & 0.02 & 0.02 & 0.02 & 0.02 & 0.85 \\
\hline
\end{tabular}


Overall, woodlands tended to change from high canopy density to low canopy density forest lands, which indicated degradation of forest stands.

\subsection{Prediction and Validation of Land Use in $\mathbf{2 0 1 0}$}

Based on land use cover in 2005, we predicted land cover distribution in 2010. Figure 2 shows the comparison between predicted land use in 2010 and actual real land use in 2010, 2005 and 2000.

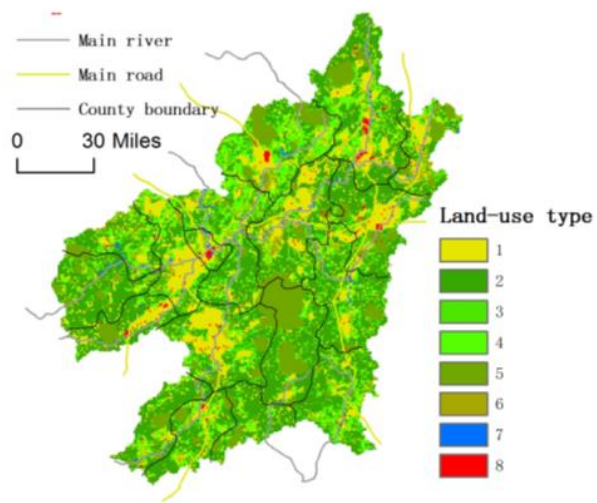

(a) Predicted Land Use in 2010

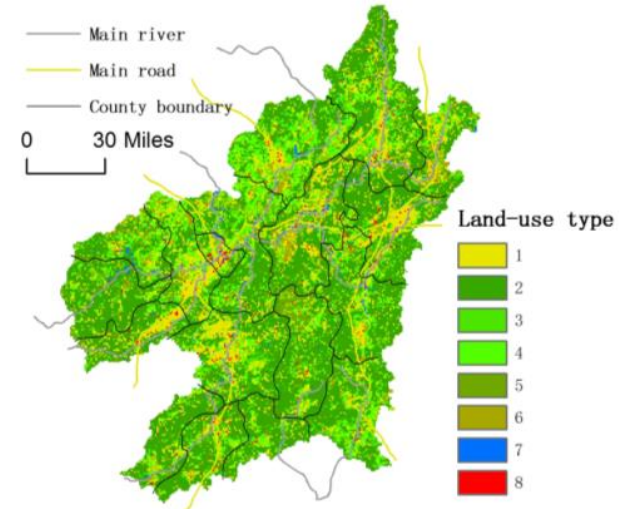

(b) Real Land Use in 2010
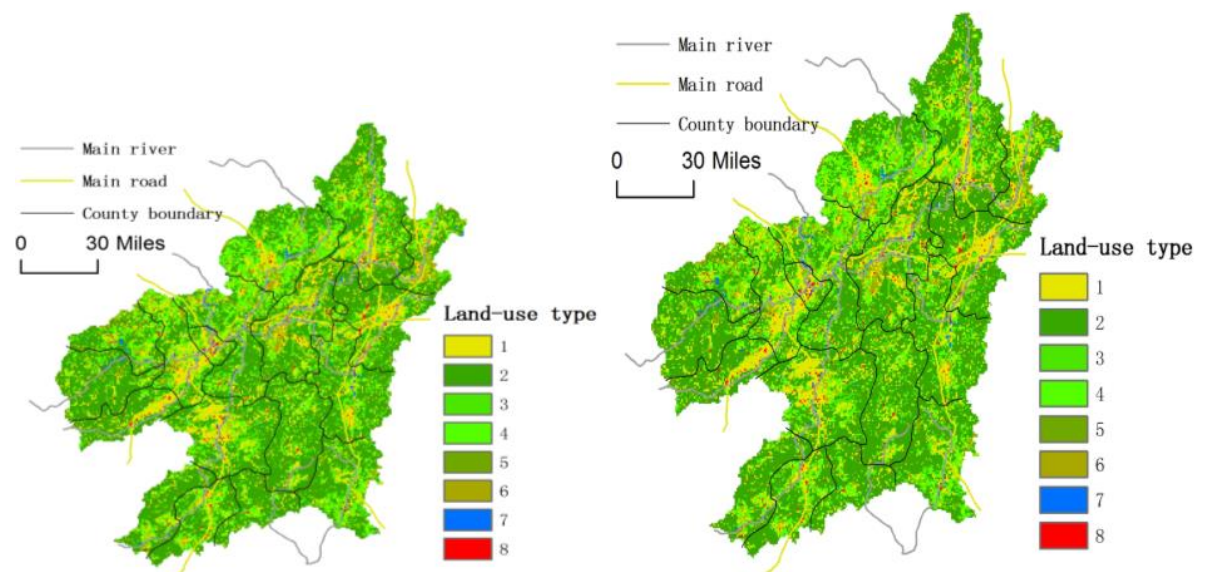

(c) Real Land Use in 2005 (d) Real Land Use in 2000

\section{Figure 2. A Comparison of Predicted in 2010 and Real Land Use in 2010, 2005 and 2000}

To validate the results, we used a point-to-point comparison method with the kappa coefficient based on real land use data for 2010. Table 3 shows the confusion matrix, where the last row gives the Kappa Index of Agreement (KIA) using real land use as reference. From the confusion matrix, CA-Markov model can be found to simulate real forest land use well. The KIA of 4 forest land use types exceeds 0.85 except closed forest land. $14 \%$ closed forest land are mistakenly predicted, especially to be other forest land, open forest land and shrubbery, which leads a underestimation of closed forest land. What's more, it is obvious that the area of other forest land is over estimated. The overall kappa value was 0.88, which is within the ideal range (Li X et al. 2007).

CA-Markov model can reflect the land cover change of Gannan forest to a certain extant. The uncertainty of the prediction is mainly caused in two aspects. Firstly, the transition matrix may fail to fully reflect the changing trend of the future. For instance, the 
real growth rate of other forest land in time period 2005-2010 is far less than that of 20002005, which leads to the overestimate of other forest land. Secondly, the transfer rule of $\mathrm{CA}$ is not easy to determine as the forest land cover change is influenced by both natural and human factor, such as DEM, slope, road, river, population density, GDP and so on.

Table 3. Confusion Matrix of the Prediction in 2010

\begin{tabular}{|c|c|c|c|c|c|c|c|c|c|}
\hline & \multicolumn{8}{|c|}{ Real Land Use } \\
\hline & & 1 & 2 & 3 & 4 & 5 & 6 & 7 & 8 \\
\hline \multirow{9}{*}{ 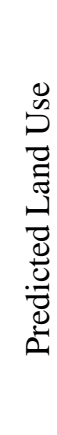 } & 1 & 6130 & 552 & 33 & 533 & 3 & 251 & 55 & 6 \\
\hline & 2 & 12 & 17042 & 38 & 7 & 50 & 31 & 0 & 2 \\
\hline & 3 & 2 & 107 & 1213 & 0 & 3 & 0 & 0 & 2 \\
\hline & 4 & 1 & 621 & 0 & 5684 & 11 & 20 & 0 & 4 \\
\hline & 5 & 623 & 2583 & 128 & 294 & 571 & 45 & 0 & 9 \\
\hline & 6 & 1 & 21 & 0 & 0 & 0 & 1808 & 0 & 9 \\
\hline & 7 & 0 & 1 & 0 & 0 & 0 & 0 & 316 & 10 \\
\hline & 8 & 121 & 2 & 4 & 0 & 1 & 0 & 0 & 322 \\
\hline & KIA & 0.88 & 0.76 & 0.85 & 0.86 & 0.89 & 0.84 & 0.85 & 0.88 \\
\hline
\end{tabular}

From the point of spatial distribution, simulation error mainly occurred in the center of regions with a large proportion of the same land use type. This is mainly because CA uses a strict definition of neighbor rules that restricts the ability to simulate real-world scenarios. On the other hand, the error also reflects that CA fails to fully consider the influence of various practical factors and random factors.

\subsection{Predicted Land Use in 2020}

As CA-Markov method has passed the precision test, we use it to predict the land cover distribution in 2020 based on the real land use of 2010. Figure 3 shows the predicted result. The predicted area for each land use type is given in Table 4.

According to the model prediction, if the patterns of land-use change for 2005-2010 continue, forest land structure in Gannan will be dramatically changed by 2020. In 2020, the total area of forest land will increase slightly, by $760 \mathrm{~km}^{2}$, but the area of open and closed forest and shrubbery will all decrease. Shrubbery and open forest land will be reduced by $21.9 \%$ and $22.4 \%$, respectively. The increase in forest land is a result of rapid growth of young afforested land, slash, plant nurseries and garden plots. Although forest land is increasingly, the quality of this land-use category is declining, and forest resources are undergoing degeneration. In addition farmland, grassland and aquatic areas are all being reduced. 


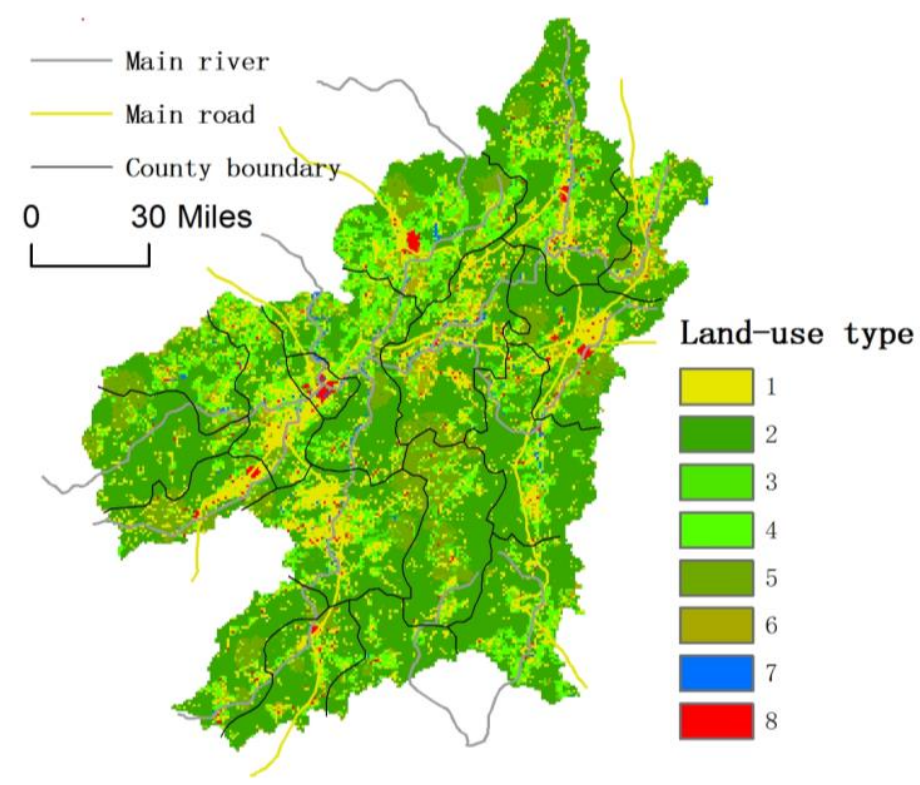

Figure 3. Predicted Land Use in 2020

Table 4. Area and Percent of Predicted Land Use in 2020

\begin{tabular}{crrrrrr}
\hline Code & Area in 2010 & Percent & Area in 2020 & Change in area & Percent & Percentage change \\
\hline 1 & 6890 & $17.54 \%$ & 6420 & -470 & $16.34 \%$ & $-1.20 \%$ \\
2 & 20929 & $53.28 \%$ & 20849 & -80 & $53.08 \%$ & $-0.20 \%$ \\
3 & 1416 & $3.60 \%$ & 1106 & -310 & $2.82 \%$ & $-0.79 \%$ \\
4 & 6518 & $16.59 \%$ & 5058 & -1460 & $12.88 \%$ & $-3.72 \%$ \\
5 & 639 & $1.63 \%$ & 3249 & 2610 & $8.27 \%$ & $6.64 \%$ \\
6 & 2155 & $5.49 \%$ & 1815 & -340 & $4.62 \%$ & $-0.87 \%$ \\
7 & 371 & $0.94 \%$ & 311 & -60 & $0.79 \%$ & $-0.15 \%$ \\
8 & 364 & $0.93 \%$ & 475 & 111 & $1.21 \%$ & $0.28 \%$ \\
\hline
\end{tabular}

\section{Conclusions}

This study predicted forest cover in Gannan, China using a combined cellular automata-Markov model. Based on land cover data for 2005-2010, we constructed a CA-Markov model to simulate landscape structure in 2020. The conclusions are as follows.

(1) Land use transfer analysis: forest lands mainly changed to other types of forest land and to farmland. The direction in which this change occurred was from other forest land types and farmland. Woodlands changed from high-canopy-density to low-canopy-density forests, which indicated degradation of forest stands.

(2) Land use simulation analysis: according to our prediction, if patterns of land use change that occurred from 2005 to 2010 continue, the extent of closed forest, shrubbery and open forest will decrease. These changes in forest land may jeopardize microclimate areas, soil and water conservation, and ecosystem services. The continuous development of forest resources in Gannan presents a serious challenge.

(3) CA-Markov simulates land cover change of Gannan forest well. The result can provide the basis for land cover monitoring and sustainable development in the study area. To further enhance the simulation precision, transition rules of cellular automata 
need to be more appropriate. CA-Markov model including influence factors and government policies needs to be built. What's more, land use data of higher spatial resolution will reduce the scale of the cellular and thus improve the precision quantitatively and spatially.

Forests in Gannan have significant ecological and economic potential. As urbanization increases rapidly, anthropogenic activity not only brings economic prosperity, but it causes environmental disruption. The shrinking of quality forest resources sounds an alarm that rational planning and land use is critical when exploiting natural resources. The government should strengthen ecological conversation to ensure the orderly proceeding of forest tending projects. In addition, an ecological compensation mechanism should be established to guarantee that forest structure is maintained consistent with policy.

\section{Acknowledgments}

The work of this paper is supported by Project of Key Research Base for Humanities and Social Sciences in Ministry of Education (Grant No. 15JJD790040), Planning Emphases Project of Key Research Base for philosophy and social science of Jiangxi Province (Grant No. 15SKJD04) and Science and Technology Project Founded by the Education Department of Jiangxi Province (Grant No. 150173), The National Natural Science Foundation of China (Grant No. 71363043 ).

\section{References}

[1] P. Cabral and A. Zamyatin, "Markov processes in modeling land use and land cover changes in SintraCascais, Portugal”, DYNA-COLOMBIA, vol. 158, (2009), pp. 191-198.

[2] G. Chen and H. Tian, "Land use/cover change effects on carbon cycling in terrestrial ecosystems", Chinese Journal of Plant Ecology, vol. 31, (2007), pp. 189-204. (In Chinese)

[3] China State Council, "Some opinions of the State Council on support Gannan former Soviet central development (NO. 21 Document of State Council)", (2012). (In Chinese)

[4] A. Falcucci, L. Maiorano and L. Boitani, "Changes in land-use/land-cover patterns in Italy and their implications for biodiversity conservation”, Landscape Ecology, vol. 22, no. 4, (2007), pp. 617-631.

[5] J. A. Foley, R. DeFries, G. P. Asner, C. Barford, G. Bonan, S. R. Carpenter, F. S. Chapin, M. T. Coe, G. C. Daily, H. K. Gibbs, J. H. Helkowski, T. Holloway, E. A. Howard, C. J. Kucharik, C. Monfreda, J. A. Patz, I. C. Prentice, N. Ramankutty and P. K. Snyder, "Global consequences of land use", Science, vol. 309, no. 5734, (2005), pp. 570-574.

[6] G. Green and S. Ahearn, "Modelling forest canopy trends with on-demand spatial simulation", International Journal of Geographical Information Science, vol. 30, no. 1, (2016), pp. 61-73.

[7] D. J. Guan, H. F. Li, T. Inohae, W. Su, T. Nagaie and K. Hokao, "Modeling urban land use change by the integration of cellular automaton and Markov model", Ecological Modeling, vol. 222, no. 20-22, (2011), pp. 3761-3772.

[8] M. C. Hansen and T. R. Loveland, "A review of large area monitoring of land cover change using Landsat data", Remoter Sensing of Environment, vol. 122, (2012), pp. 66-74.

[9] A. J. Jokar, M. Helbich, W. Kainz and B. A. Darvishi, "Integration of logistic regression, Markov chain and cellular automata models to simulate urban expansion", International Journal of Applied Earth Observation and Geoinformation, vol. 21, (2013), pp. 265-275.

[10] R. Kumar, S. Nandy, R. Agarwal and S. P. S. Kushwaha, "Forest cover dynamics analysis and prediction modeling using logistic regression model", Ecological Indicators, vol. 45, (2014), pp. 444455.

[11] E. F. Lambin, H. J. Geist and E. Lepers, "Dynamics of land-use and land-cover change in tropical regions", Annual Review of Environment and Resources, vol. 28, (2003), pp. 205-241.

[12] X. Li, A. G. Yeh and X. Liu, "Geographical Simulation Systems: Cellular Automata and Multi-agent Systems", Science Press, Beijing, (2007). (In Chinese)

[13] J. Liu and X. Deng, "Progress of the research methodologies on the temporal and spatial process of LUCC", Chinese Science Bulletin, vol. 55, no. 14, (2010), pp. 1354-1362. (In Chinese)

[14] D. Martinez, E. Castillo, A. Garcia-Martin, Longares and L. A. Aladren, "Evaluation of forest cover change using remote sensing techniques and landscape metrics in Moncayo Natural Park (Spain)", Applied Geography, vol. 62, (2015), pp. 247-255.

[15] A. L. Mayer, P. E. Kauppi, P. K. Angelstam, Y. Zhang and P. M. Tikka, "Ecology Importing timber, exporting ecological impact”, Science, vol. 308, no. 5720, (2005), pp. 359-360. 
[16] A. J. Mousivand, Alimohammadi, A. Sarab and S. Shayan, "A new approach of predicting land use and land cover changes by satellite imagery and Markov chain model (Case study: Tehran)", MSc Thesis. Tarbiat Modares University, Tehran, Iran, (2007).

[17] A. Mukhopadhyay, P. Mondal and J. Barik, "Changes in mangrove species assemblages and future prediction of the Bangladesh Sundarbans using Markov chain model and cellular automata", Environmental Science-Processes \& Impacts, vol. 17, no. 6, (2015), pp. 1111-1117.

[18] J. Muellerova, P. Szabo and R. Hedl, "The rise and fall of traditional forest management in southern Moravia: A history of the past 700 years", Forest Ecology and Management, vol. 331, (2014), pp. 104115.

[19] J. T. Overpeck, D. Rind and R. Geoldberg, "Climate-induced changes in forest disturbance and vegetation", Nature, vol. 343, no. 6253, (1990), pp. 51-53.

[20] P. Rujan, "Cellular Automata and Statistical Mechanical Models", Journal of Statistical Physic, vol. 49, no. 1-2, (1987), pp. 139-222.

[21] P. Serra, X. Pons and D. Sauri, "Land-cover and land-use change in a Mediterranean landscape: A spatial analysis of driving forces integrating biophysical and human factors", Applied Geography, vol. 28, no. 3, (2008), pp. 189-209.

[22] T. Simoniello, R. Coluzzi, V. Imbrenda and M. Lanfredi, "Land cover changes and forest landscape evolution (1985-2009) in a typical Mediterranean agroforestry system (high Agri Valley)", Natural Hazards and Earth System Sciences, vol. 15, no. 6, (2015), pp. 1201-1214.

[23] P. K. Srivastava, A. Mehta, M. Gupta, S. Singh and T. Islam, "Assessing impact of climate change on Mundra mangrove forest ecosystem, Gulf of Kutch, western coast of India: a synergistic evaluation using remote sensing", Theoretical and Applied Climatology, vol. 120, no. 3-4, (2015), pp. 685-700.

[24] X. Song, X. Guo and X. Li, "Discussion of sustainable development in Gannan's Forestry Industry", Forest By-Product and Speciality in China, vol. 135, (2015), pp. 86-87. (In Chinese)

[25] C. Tattoni, M. Ciolli and F. Ferretti, "The fate of priority areas for conservation in protected areas: A fine-scale Markov chain approach", Environmental Management, vol. 47, (2011), pp. 263-278.

[26] "The fourth session of the Tenth National People's Congress", The Eleventh Five-Year Plan, Beijing, (2006). (In Chinese)

[27] K. Uddin, S. Chaudhary, N. Chettri, R. Kotru, M. Murthy, R. Chaudhary, N. Wu, S. M. Shrestha and S. K. Gautam, "The changing land cover and fragmenting forest on the Roof of the World: A case study in Nepal's Kailash Sacred Landscape", Landscape Urban Planning, vol. 141, (2015), pp. 1-10.

[28] P. H. Verburg, K. Neumann and L. Nol, "Challenges in using land use and land cover data for global change studies", Global Change Biology, vol. 17, no. 2, (2011), pp. 974-989.

[29] D. A. Wardell, A. Reenberg and C. Tettrup, "Historical footprints in contemporary land use systems: forest cover changes in savannah woodlands in the Sudano-Sahelian zone", Global Environmental Change Human and Policy Dimensions, vol. 13, no. 4, (2003), pp. 235-254.

[30] R. Zhang, C. Tang, S. Ma, H. Yuan, L. Gao and W. Fan, "Using Markov chains to analyze changes in wetland trends in arid Yinchuan Plain", China. Mathematical and Computer Modeling, vol. 54, no. 3-4, (2011), pp. 924-930. 